\title{
Benefits of maternal vaccination to prevent pertussis in infants
}

\author{
Álvaro Monterrosa-Castro*, Andrea Ramírez-García, Teresa Beltrán-Barrios
}

Grupo de Investigación Salud de la Mujer. Facultad de Medicina. Universidad de Cartagena, Colombia

Received: 07 August 2017

Accepted: 04 September 2017

\section{*Correspondence:}

Dr. Álvaro Monterrosa-Castro,

E-mail: alvaromonterrosa@gmail.com

Copyright: ( ) the author(s), publisher and licensee Medip Academy. This is an open-access article distributed under the terms of the Creative Commons Attribution Non-Commercial License, which permits unrestricted non-commercial use, distribution, and reproduction in any medium, provided the original work is properly cited.

\begin{abstract}
Pertussis, also called whooping cough, is an infectious and preventable pathology that generates important child morbidity and mortality worldwide. There are different biological preparations for its use in infants, while for adolescents and adults is Tdap, (acellular vaccine of purified extracts of Bordetella pertussis (BP), combined with tetanus and diphtheria toxoid) that has been proposed as maternal vaccination (MV). The objective was to identify the benefits of MV in the prevention of childhood pertussis, a review was made in PubMed, Science Direct, EBSCOhosT, OvidSP and Embase databases (years 2008-2016) and an electronic alert system (January-April 2017). 1083 titles were identified and 44 articles were selected. After the MV (administered between 27 and 36 weeks of gestation) the passage of IgG-BP to the fetus is sufficient to generate adequate infant protection, generating two benefits: reducing infant morbidity (number of cases and hospital admissions) and decreasing mortality by pertussis. The MV offers 93\% of effectiveness [95\%CI: 81-97] and OR: 0.09 [95\%CI: 0,03-0,25]. The MV is more favorable in each pregnancy than cocoon strategy, vaccination before pregnancy, before 26 weeks of gestation or in the postpartum. The use of MV is a safe and cost-effectiveness tool to prevent childhood pertussis.
\end{abstract}

Keywords: Infant mortality, Obligatory vaccination, Pertussis, Prenatal Care, Vaccination

\section{INTRODUCTION}

Pertussis, also called whooping cough, is an acute, infectious and usually severe respiratory disease with high mortality in infants younger than six years. ${ }^{1-3}$ It is caused by Bordetella pertussis (BP) that is a cocobacillus exclusive in humans; it is transmitted by minute and contaminated particles that come from respiratory epithelium of the patient. ${ }^{1,4}$ Germs of the same species, $B$. parapertussis and $B$. holmesii, are involved just like $B$. bronchiseptica (a pathogen that affects animals) but it also can infect immunocompromised patients. ${ }^{7}$

The pertussis disease causes respiratory compromise, rhinorrhea, sneezing, fever, cough and cyanosis by the accumulation of mucopurulent exudates in the respiratory tract. ${ }^{5,8}$ Adults or children usually infect the newborns. ${ }^{9,10}$
Frequently, this illness appears in the childhood but it can affect at any age. ${ }^{9-14}$

Pertussis generates high rates of infant morbidity and mortality. It is a health public problem and its epidemic peaks have increased, for that reason, the notification is mandatory. ${ }^{1,3,5,15-19}$ The World Health Organization pointed out that the number of notified cases around the world in 2012 was 249.556; 71.774 (28,7\%) of them were in America. ${ }^{20}$ The Center for Disease Control and Prevention from EEUU, showed that, in that country, the reported cases were 28.639 in 2013 and 32.971 in 2014 with a rise of $15 \% .^{5}$ The highest rates were among adolescents and most of the deaths were in newborns less than three months of age. Pertussis is usually mild, moderate or even subclinical in adults and adolescents but it can be severe and produce pneumonia, convulsions and encephalopathy. ${ }^{5,8-10,21,22}$ 
In Colombia, during 2012, 11,404 pertussis cases were notified: 3,290 (28.8\%) confirmed, $739(6.4 \%)$ probable and 7,375 (64.6\%) discarded; 69 patients died and 62 of them were under six months of age. The notifications grew to 13.626 and the confirmed cases were reduced to 2.754 in the next year. The incidence of confirmed cases was 8.5/100,000 inhabitants in 2012 and 5.5/100,000 inhabitants in 2013. ${ }^{15,23}$ Pertussis is considered as a reemerging illness, in that sense, the Pan American Health Organization found that the number of cases had increased in Argentina, Brazil, Colombia, Chile, Guatemala, Mexico, Paraguay, Venezuela and United States of America. ${ }^{18}$

The main strategy to prevent pertussis is to vaccinate infants, adolescents and adults. ${ }^{8,15}$ It is recommended applying the vaccine around two, four or six months of age with a new application at one years old and then at five years old. The vaccine is a compound of 15-20 millions of inactivated bacilli in formaldehyde; the triple bacterial vaccine is a pharmaceutical method combined with vaccines against diphtheria and tetanus. Other vaccine, called pentavalent, includes hepatitis B and Haemophilus influenza. ${ }^{15}$ Additionally, the acellular vaccine is approved to be administrated since two months of age. ${ }^{8}$ The absence of vaccination under that age makes the infant vulnerable to pertussis, it is for that reason that maternal vaccination (MV) is an interesting strategy to overcome this situation. ${ }^{21,24-26}$ Tdap (acellular vaccine of purified extracts of adhesion molecules BP combined with tetanus toxoid and reduced diphtheria toxoid) can protect adolescents and adults, it is administrated with just one dose..$^{1,4,5,15,19,23}$ The objective of this revision was to identify the benefits of MV to prevent infant pertussis.

\section{Literature review}

Bibliographic investigation with a narrative revision. Clinical and epidemiologic studies, systematic revisions, consensus, expert meetings, meta-analysis, clinical guides and protocols were included. Type of participants: published articles about MV to prevent infant pertussis. Research strategy: it was carried out an electronic research in PubMed, ScienceDirect, EBSCOhost, OvidSP and Embase data bases between 2008 and 2016, as well as in Scielo, in the same period of time, but in Spanish. It was created an electronic alert system with the term maternal immunization in the period between January and April, 2017.

The tittles were identified and those repeated were eliminated. The summaries were revised to select those adjusted to the objective of this research. Two rounds of selection were carried out and the revision was done with the relevant articles (all the documents selected were in full text format). Another group of articles was added with the snowball sampling. The articles were checked separately taking into account the relevant contents in a data table in Microsoft Excel.
One thousand and eighty titles were identified, 402 of them $(37.2 \%)$ was repeated, that's why 678 , in which the summaries had been revised, were preserved. Three hundred ninety-three articles did not adjust to the objective and were discarded. The remaining 285 $(42.0 \%)$ were acquired in full text format. After that, at the first selection, 131 tittles were selected (46.6\%); in the second selection, only 41 articles were considered appropriate. Additionally, with the alert system three publications were obtained from 2017 that, after being reviewed, were chosen.

\section{Maternal vaccine and infant immunogenicity}

The MV is a strategy, which aims to preserve healthy to the pregnant mother as well as taking advantage of the passage of antibodies through the placenta and generating immunity in the infant before he/she receives his routine vaccines. $3,6,9,12,13,24,27-29$

Regarding pertussis, immunogenic capacity that can be achieved with MV is observed in the clinical trial of Hoang, who administrated Tdap (in the group A) or a vaccine against tetanus (in the group B) in pregnant women from Vietnam. ${ }^{30}$ There were no differences about IgG-BP among the groups before the vaccination: group A: 8,2 IU/ml [95\%IC:6,4-10,6]; group B: 7,9 IU/ml [95\%IC:4,9-10,4]. One month after vaccination, the IgG$\mathrm{BP}$ raised to $33,1 \mathrm{IU} / \mathrm{ml}$ [95\% IC:4,3-7,6] in the Tdap group; this was not evaluated in the other group. At the time of delivery, the levels were: group A: 17,3 IU/ml [95\%IC:13,0-22,0; group B: 5,7 IU/ml [95\%IC:4,3-7,6], $\mathrm{P}<0,001$. It was detected the same difference in an umbilical cord sample: 21,0 IU/ml [95\% IC:16,0-28,0] compared to $7,2 \mathrm{IU} / \mathrm{ml}[95 \% \mathrm{IC}: 5,6-9,4]$. The difference remained significant before the vaccination of infants, 4,2 $\mathrm{IU} / \mathrm{ml} \quad[\mathrm{CI} 95 \%: 2,9-5,9]$ and $0,8 \mathrm{IU} / \mathrm{ml}$ [95\%CI:0,5$1,3], \mathrm{P}<0,001$. One month after completing the childhood vaccination there were no differences between groups of infants, 70,0 IU/ml [95\%CI: 58,0-84,0] group A and 67.0 IU/ml [95\%CI: 53,0-84,0] B-group, $\mathrm{p}=0.73$. The findings were similar in antibodies against filamentous hemagglutinin and pertactin, two antigenic factors of virulence of $\mathrm{BP}$.

The immunogenic impact is different according to the MV moment. ${ }^{27}$ Healy found that pregnant preconceptionally vaccinated women, or in early pregnancy, did not present the necessary passage of the antibodies through the placenta to generate the prevention of pertussis in the infant. ${ }^{29,31}$ Therefore, Tdap must be administered between 27-36 weeks of gestation. ${ }^{5}$ The antibodies declined rapidly, so it is necessary to repeat the vaccination in each pregnancy. ${ }^{9,12,32}$ It has been generally accepted that newborns with mothers vaccinated with Tdap during the third trimester of pregnancy have enough anti-BP antibodies to be protected before receiving the children's scheme. ${ }^{13,21,24,27,33}$ 
Table 1: Infant morbidity and mortality reduction by pertussis.

\begin{tabular}{|c|c|c|c|}
\hline Author & Country/Year & Study & Findings \\
\hline Baxter, et al. & $\begin{array}{l}\text { United States } \\
2017\end{array}$ & $\begin{array}{l}\text { Retrospective cohort of } \\
148.981 \text { infants from a } \\
\text { health care organization. } \\
\text { Exposure: maternal Tdap } \\
\text { application. }\end{array}$ & $\begin{array}{l}\text { Effectiveness to reduce pertussis in the first two months of the } \\
\text { infant's life. Effectiveness of the maternal vaccine: } 91,4 \% \text { [95\%CI: } \\
\text { 19,5-99,1]. Effectiveness of the vaccine applied before pregnancy: } \\
68,6 \% \text { [95\%CI: }-44,9 \text { to } 93,2 \text { ]. Effectiveness of the vaccine } \\
\text { applied to mothers after childbirth: } 45,7 \% \text { [IC95: }-88,2 \text { to } 84,3 \text { ]. }\end{array}$ \\
\hline Winter, et al. & $\begin{array}{l}\text { United States } \\
2017\end{array}$ & $\begin{array}{l}\text { Retrospective cohort of the } \\
\text { California regional } \\
\text { vaccination registry. The } \\
\text { Tdap in pregnancy or in } \\
\text { the first } 14 \text { days } \\
\text { postpartum. }\end{array}$ & $\begin{array}{l}\text { Effectiveness of the vaccine applied between } 27-36 \text { weeks } \\
\text { gestation, compared to postpartum administration: } 85,4 \% \text { [ } 95 \% \text { CI: } \\
33,0-96,7 \text { ] for prevention in children younger than } 4 \text { weeks of age } \\
\text { and } 72,0 \% \text { [ } 95 \% \text { CI: } 30,0-89,0 \text { ] for prevention in children under } 12 \\
\text { weeks of age. Effectiveness of the vaccine applied at any time } \\
\text { during pregnancy compared to the postpartum vaccine: } 63,8 \% \\
\text { [95\%CI: } 10,6-85,4] \text {. Vaccination between } 27-36 \text { weeks of } \\
\text { gestation was more protective than before or after. }\end{array}$ \\
\hline Vizzoti, et al. & $\begin{array}{l}\text { Argentina } \\
2016\end{array}$ & $\begin{array}{l}\text { Data analysis of the health } \\
\text { surveillance system. } \\
\text { Division of the country in } \\
\text { regions of high and low } \\
\text { coverage of maternal } \\
\text { vaccination. }\end{array}$ & $\begin{array}{l}\text { Reduction of pertussis, high comparison with low coverage: } 51 \% \\
\text { [95\%CI: } 35-67], p<0,001 \text {. } \\
\text { Reduction of pertussis, comparison of infants less than two } \\
\text { months of age with six months of age: } 44 \% \text { [95\% CI: } 24- \\
66], p<0,001 \text {. }\end{array}$ \\
\hline Dabera, et al. & $\begin{array}{l}\text { United } \\
\text { Kingdom } \\
\text { (England and } \\
\text { Wales)2015 }\end{array}$ & $\begin{array}{l}\text { Cases-control study. } \\
\text { Cases=children younger } \\
\text { than } 8 \text { weeks of age with } \\
\text { confirmed pertussis (PCR } \\
\text { or culture). Controls = } \\
\text { children without pertussis. } \\
\text { Exposure: maternal } \\
\text { application of Tdap. }\end{array}$ & $\begin{array}{l}\text { Effectiveness not adjusted: } 91 \% \text { [95\%CI: 77-97] } \\
\text { Effectiveness adjusted: } 93 \% \text { [95\%CI: 81-97] } \\
\text { Maternal vaccination, OR: 0,09 [IC95\%: 0,03-0,25] }\end{array}$ \\
\hline $\begin{array}{l}\text { Fernández, et } \\
\text { al. }\end{array}$ & $\begin{array}{l}\text { Spain } \\
2015\end{array}$ & $\begin{array}{l}\text { Cost/benefit analysis. } \\
\text { Estimate of the needed } \\
\text { number to vaccinate } \\
\text { (NNV). Two groups: } \\
\text { maternal vaccination and } \\
\text { cocoon strategy. }\end{array}$ & $\begin{array}{l}\text { The number of parents, cocoon strategy, needed to vaccinate } \\
\text { (NNV) to prevent hospitalization of children aged } 0-2 \text { months was } \\
6.616 \text {. To prevent hospitalization in children under one year was } \\
4.752 \text { and to prevent one death was } 936.715 \text {. The cost of } \\
\text { vaccination to prevent a death was } 15.783 .648 \text { EUR. With } \\
\text { maternal vaccination the NNV was } 1.451 \text { to prevent } \\
\text { hospitalization in infants from } 0-2 \text { months, of } 1.331 \text { to prevent } \\
\text { hospitalization in children under one year and } 205.420 \text { to prevent } \\
\text { one death. The cost of vaccination to prevent a death was } \\
\text { 3.461.326 EUR. }\end{array}$ \\
\hline $\begin{array}{l}\text { Amirthalingam, } \\
\text { et al. }\end{array}$ & $\begin{array}{l}\text { England } \\
2014\end{array}$ & $\begin{array}{l}\text { Data Analysis Public } \\
\text { Health System. } \\
\text { Comparison } 2012 \text { without } \\
\text { vaccination and } 2013 \text { with } \\
\text { maternal vaccination. }\end{array}$ & $\begin{array}{l}\text { Confirmed cases: } 36 \% \text { reduction [95\%CI: 33-38]. Hospital } \\
\text { admission: reduction of 58\% [95\%CI: } 37-63] \text {. In younger children } \\
\text { three months, confirmed cases reduced to } 80 \% \text { [95\%CI: } 69-87 \text { ] } \\
\text { and admission to hospital, reduction of } 66 \% \text { [95\%CI: } 57-75] \text { ]. } \\
\text { Effectiveness of maternal vaccination for pertussis prevention in } \\
\text { children under three months: } \\
91 \% \text { [95\%CI: } 84-95] \text {. }\end{array}$ \\
\hline $\begin{array}{l}\text { Terranella, et } \\
\text { al. }\end{array}$ & $\begin{array}{l}\text { United States } \\
2013\end{array}$ & $\begin{array}{l}\text { Cohort study. Compare } \\
\text { Tdap in pregnancy, } \\
\text { postpartum and cocoon } \\
\text { strategy, (postpartum, } \\
\text { father and grandfather). }\end{array}$ & $\begin{array}{l}\text { Case reduction, maternal vaccination: } 33 \% \text {, maternal vaccination } \\
\text { postpartum: } 20 \% \text {, cocoon strategy: } 32 \% \text {. Reduction hospitalization } \\
\text { respiratory events, maternal vaccination: } 30 \% \text {, maternal } \\
\text { vaccination postpartum: } 19 \% \text {, "cocoon strategy": } 32 \% \text {. Reduction } \\
\text { of hospitalization in neurological events: maternal vaccination: } \\
33 \% \text {, maternal vaccination postpartum: } 20 \% \text {, cocoon strategy: } \\
32 \% \text {. Reduction of mortality, maternal vaccination: } 49 \% \text {, maternal } \\
\text { vaccination postpartum: } 16 \% \text {, cocoon strategy: } 29 \% \text {. }\end{array}$ \\
\hline $\begin{array}{l}\text { Meregaglia, et } \\
\text { al. }\end{array}$ & $\begin{array}{l}\text { Italy } \\
2013\end{array}$ & $\begin{array}{l}\text { Data from clinical cases } \\
\text { reported in a surveillance } \\
\text { system. Hospitalizations in } \\
\text { children under } 12 \text { months } \\
\text { of age. Cocoon strategy } \\
\text { intervention and no } \\
\text { vaccination. }\end{array}$ & $\begin{array}{l}\text { In } 2009-2010 \text { non-vaccination, } 46 \text { hospitalizations. Attributable } \\
\text { transmission risk of } 32 \%=33 \text { hospitalizations, vaccine } \\
\text { effectiveness: } 28.3 \% \text {. Assignable transmission risk of } 40 \%=30 \\
\text { hospitalizations, vaccine effectiveness: } 34.8 \% \text {. } \\
\text { Attributable transmission risk of } 55 \%=23 \text { hospitalizations, } \\
\text { vaccine effectiveness: } 50 \% \text {. At low incidence of pertussis, the } \\
\text { cocoon strategy may be poorly effective. }\end{array}$ \\
\hline
\end{tabular}


In addition, the MV with Tdap offers two benefits: reducing morbidity and decreasing the infant mortality caused by pertussis (Table 1).

\section{Reduction of infant morbidity by pertussis}

Possibly this is due to the passage of maternal/fetal antibodies and the prevention related to the transmission of germs from the maternal respiratory tract. ${ }^{3,12}$ Amirthalingam evaluated different population groups before and after the introduction of Tdap as MV. ${ }^{34}$ There was a reduction in the $36 \%$ of confirmed pertussis cases, from 5,909 cases in 2012 to 3,795 in 2013, which represents a decrease of $58 \%$ in the admission to the hospital at all ages. The reduction percentages were higher in children under three years-old: $80 \%$ in confirmed cases and $66 \%$ in hospital admission. The MV efficacy was $91 \%$ in newborns under three months of age, if the vaccination had been carried out seven days before the delivery. No differences were found about the efficacy when it was compared to the MV carried out between 7 and 27 days before the delivery and at least 28 days before the birth.

In other situation, the efficacy decreased to $38 \%$ when the MV was carried out from 0 to 6 days before the delivery, or 1 or 3 days after the birth. Terranella found similar findings and observed that the $\mathrm{MV}$ reduce more the incidence of infant pertussis and its hospitalizations by respiratory complications than postpartum maternal vaccination (PMV): 33 and 38\% versus 20 and 19\%, respectively. ${ }^{13}$ If it is carried out a PMV joined to a vaccination of the father and the grandfather, the figures will be similar to MV and the costs would be more elevated. Carcione did not identify differences in infant pertussis cases when the two parents were vaccinated in postpartum compared to those who did not get the vaccination: $1,9 / 1000$ vs. 2,2/1000, HR: 0,91 [95\% IC:0.55-1.53]. Besides, the PMV was not protective: HR: 1,19 [95\%IC: $0,82-1,72] .{ }^{35}$

A case-control study pointed out about the good efficacy of Tdap applied as MV to prevent infant pertussis with a 93\% adjusted by gender, geographic area and period at birth, it was similar to the observed reduction in the same population since the introduction of MV. ${ }^{36}$ Equally, a cohort study analyzed 148,881 newborns, of which 17 presented pertussis at the first two months of age; it was estimated an efficacy of $91.4 \%$ in the administration of MV eight days before the delivery and $45.7 \%$ for PMV. Vizzotti estimated a reduction of pertussis of $51 \%$ in the high vaccination coverage compared to the low vaccination one. ${ }^{37}$ When infants between 2 and 6 months of age were compared to infants older than six years-old it was detected a decrease of $44.0 \%$. The aforementioned study seems the first to demonstrate the reduction of infant pertussis with MV in a developed country.

Due to the intrafamiliar contagion, where the parents are the transmitters in the $50 \%$ of the cases: grandparents with $8 \%$ and siblings with $20 \%$, it has been proposed to apply the cocooning vaccination, also known as the cocoon strategy, to parents, relatives, caregivers and close friends..$^{8,13,17}$ This vaccination is characterized by its controversial cost-effectiveness and its difficult application but it is considered effective and safe., ${ }^{3,12}$ Meregaglia estimated the necessary number of vaccinations, using the cocoon strategy, to prevent the hospital admission of infants with pertussis. ${ }^{22}$ Moreover, the author concluded that 10,000 vaccinations must be applied to prevent the hospitalization in infants under 12 months, assuming that the parents had $32 \%$ risk of illness for the patients. Seventy-seven hospital admissions were found by pertussis in children under 3 months years old in the period between 2005-2010 for a rate of 34/10,000 inhabitants. If the risk of attributable transmission were $55 \%, 23$ hospitalizations and $50 \%$ of effectiveness would be expected. The cocoon strategy is applied in several countries, especially in those where the morbidity is high; however, it has been said that this strategy is not suitable when the coverages of the vaccination are deficient. ${ }^{38,39}$

\section{Infant mortality reduction by pertussis}

The entity is endemic in many places and it can cause the death of newborns. $3,8,40,41$ According to Chilean studies, 16 infants under six months of age died in 2011; 13 of 1,240 notifications with a fatality rate of $1.04 \%$ in 2012 ; three newborns died in 2013 and seven in 2014. ${ }^{16}$ In United Kingdom were reported sixteen deaths by pertussis in infants under three months old that were born before the introduction of MV. 513 hospitalizations were registered in children of the same age and in the same period of time, which allowed to estimate a rate of fatal cases of $3,1 \%$ [95\% IC: 1,7-4,7]. ${ }^{12}$ The death by confirmed pertussis in 17 infants between 2 and 9 weeks that born to unvaccinated mothers. ${ }^{34}$ By means of a model that involves rates by year, Jan van Hoek considered the MV is effective to prevent the death of infants by pertussis, also is possible that the amount of deaths would be underestimated. ${ }^{12}$ At the same time, Terranella concluded that the MV reduces the infant mortality by pertussis in a greater proportion than cocoon strategy, whose impact is less than PMV. ${ }^{13}$ Fernández estimated that in Spain the MV was more favorable than cocoon strategy to reduce the mortality by pertussis in newborns under one year. ${ }^{42}$

\section{Security and cost/effectiveness}

As with MV, there has been a reduction in infant morbidity and mortality by pertussis, it is universally recommended using the vaccine in prenatal care. . $^{3,18,21,25}$ However, it is important to note what has been defined in terms of security. Kharbanda, in a cohort study, noted that the MV was not associated with preterm birth RR; 1,03 [95\% CI: 0,97-1,09], small for gestational age RR:1,00 [95\%CI: 0,96-1,06]) or hypertensive disorders RR: 1,09 [95\%CI: 0,99-1,20). ${ }^{19}$ The same author found association with chorioamnionitis RR: 1,19 [95\%CI: 
1,13-1,26], with small effect and possible confounding factor that needs to be extensively analyzed. Others authors have not observed adverse events in women, fetuses or neonates. ${ }^{43-45}$ In a cohort study (46) were compared pregnant women with 32 or more weeks of pregnancy who accepted the MV with others who did not accept it, without observing differences in maternal adverse events, neonatal death, congenital malformations, APGAR, umbilical cord blood $\mathrm{pH}$, chorioamnionitis, UCI need or artificial ventilation. Zheteyeva also did not identify fetal or neonatal fatal events; he suggested applying a MV with Tadp in all pregnant women, considering the intervention as safe. ${ }^{47}$

It is also important to establish the relation between cost and effectiveness. ${ }^{8}$ Sartori concluded that the MV was better in Brazil in terms of cost-effectiveness and was a more useful intervention to prevent cases and deaths by pertussis in infants than not administering it. ${ }^{48}$

Five years earlier, Westra in the Netherlands, considered that the cocoon strategy and MV were cost-effectiveness interventions with increase in the cost of EUR 9.140.000 [95\%CI: 9.082 .000 to 9.333.000] and EUR 4.053.100 [95\%CI: 3.982 .400 to 4.456 .300$]$, respectively. ${ }^{11} \mathrm{He}$ estimated a profit of annual quality of life (QALY) due to lower disease and less death by the vaccination with 1.975 [95\%CI: 438-3.805] for cocoon strategy and 1.166 [95\%CI: 282-2.326] for the MV, calculating the rate of increase in cost-effectiveness (ICER)/QALY: EUR 4.600 [95\% CI: 2.200 to 17.800$]$ and EUR 3,500 [95\%CI: 1,700-15,000], respectively. It was estimated the ICER/QALY 329.900 EUR [IC95: 256.900 to 1.071.400] for PMV. It is established that the ICER/QALY is calculated for each community and if it is less than EUR 20.000 it identifies intervention cost-effectiveness, so PMV is not cost-effectiveness as opposed to cocoon strategy and MV, being the first of these more expensive to implement but it generates a greater number of QALY. In the United States, the cost/QALY for MV was lower than for PMV: US \$ 414.523 and US \$ 1.172.825, respectively. ${ }^{13}$

Fernández estimated that the MV was more favorable than cocoon strategy in number needed to vaccinate (NNV) and in cost/benefit in Spanish population. ${ }^{42}$ However, Lugnér studied the sensitivity in the Netherlands and compared the cost-effectiveness of three infant protection strategies against pertussis: infant vaccination in the first two months, MV and PMV, the last one had a more attractive ICER, 890.00 EUR/QALY with annual cost of 1.8 million. ${ }^{9}$ The MV had 126.000 EUR/QALY and annual cost of three million Euros. The PMV had 318.000/QALY and cost 3.7 million euros/year. So that, none of the three strategies was costeffectiveness according to thresholds established in said country (EUR 20.000-50.000).

It has been pointed out that cocoon strategy is not efficient to reduce hospitalizations and deaths in communities with a low incidence of infection. ${ }^{22}$ About this, Skowronski showed that in the period between 2005 and 2009 in Canada, the NNV was over 10.000 to prevent one hospitalization and one million to prevent death of infants younger than one year. ${ }^{41}$

As the incidence becomes lower, the needed resources to achieve a further reduction are greater. In the study conducted in Italy, where it was also determined that the NNV to prevent hospitalization in younger children of one year was 10.000 , the cost per case avoided was high: greater than EUR $100.000 .^{22}$ It should be kept in mind that cost/effectiveness is dependent on the incidence, which for future years may be uncertain. ${ }^{12}$ In the Spanish population, the cost of vaccination to prevent death is much greater with the cocoon strategy than with the MV: EUR 15.783.648 compared with EUR 3.461.326, respectively. ${ }^{42}$

In 2011 the Center for Disease Control [CDC] and Prevention's Advisory Committee on Immunization Practices [ACIP] recommended Tdap to pregnant women who previously had not received it; in 2013 it was extended to each pregnancy, independent of the previous vaccination and between 27-36 weeks of gestation $(1,43){ }^{49}$ Similarly, the entities indicated to avoid previous recommendations about the use of PMV. ${ }^{50}$

The Global Pertussis Initiative, an international expert group on pertussis, recommended the $\mathrm{MV}$ as a first-line intervention, and cocoon strategy as a second line to decrease pertussis in infants in 2015.51 The WHO demonstrated that the $\mathrm{MV}$ is an important costeffectiveness strategy for preventing pertussis in infants who do not yet receive the regular vaccination schedule. ${ }^{8}$ This coincides with the findings of Vilajeliu, who found a strong correlation between levels of IgG-BP antibodies in mothers and in their infants. ${ }^{14}$ The immunogenic efficacy to reduce infant morbidity and mortality has a favorable impact on health care, family and social conditions. ${ }^{52}$

Although, the MV is more favorable than the coccon strategy to apply Tdap in parents, siblings, grandparents or health personnel who have contact with infants less than 12 months old; it is a complementary strategy to administrate the vaccine at least two weeks before the contact. $3,8,29,35$

The coverage of the MV should be increased universally; a study in the French population showed a change from $22 \%$ in 2009 to $61 \%$ in $2014 .{ }^{17,10,35,50}$ Entities that develop public health care policies must offer and stimulate the MV to prevent childhood pertussis in the third trimester. ${ }^{2,16,27,35,50,53}$ Health professionals must timely enforce vaccination, which is an activity that is part of the prenatal control. ${ }^{10,50}$ Beside, at pregnancy, Tdap can be given concurrently with the influenza vaccine and it remains safe in pregnant women who previously received a vaccine against tetanus. ${ }^{2,45}$ 


\section{CONCLUSION}

The MV with Tdap generated two benefits in terms of the prevention of childhood pertussis. First, there was a reduction in the number of cases reported and in the hospital admission. Second, the decrease in mortality at the first months of age. The MV is a safe strategy for pregnant women, fetus and neonates; also, it is more costeffectiveness than cocoon strategy and PMV.

Funding: Financial resources provided by the Universidad de Cartagena, Colombia. Plan for strengthening research for groups categorized by Colciencias and endorsed by the Universidad de Cartagena. Resolution 03707 of 2014. Act of engagement 070-2015 between the Universidad de Cartagena and the Research group Salud de la Mujer

Conflict of interest: None declared

Ethical approval: Not required

\section{REFERENCES}

1. Varan AK, Esteves-Jaramillo A, Richardson V, Esparza-Aguilar M, Cervantes-Powell P, Omer SB. Intention to accept Bordetella pertussis booster vaccine during pregnancy in Mexico City. Vaccine. 2014;32:785-92.

2. Sukumaran L, McCarthy NL, Kharbanda EO, McNeil MM, Naleway AL, Klein NP, et al. Association of Tdap vaccination with acute events and adverse birth outcomes among pregnant women with prior tetanus-containing immunizations. JAMA. 2015;314(15):1581-7.

3. Swamy GK, Wheeler SM. Neonatal pertussis, cocooning and maternal immunization. Expert Rev Vaccines. 2014;13(9):1107-14.

4. Talbot EA, Brown KH, Kirkland KB, Baughman AL, A Halperin SA, Broder KR. The safety of immunizing with tetanus-diphtheria-acellular pertussis vaccine (Tdap) less than 2 years following previous tetanus vaccination: experience during a mass vaccination campaign of healthcare personnel during a respiratory illness outbreak. Vaccine. 2010;28(50):8001-7.

5. Centers for Disease Control and Prevention (CDC). Pertussis (Whooping Cough). Disponible en: https://www.cdc.gov/pertussis/index.html. Accessed on 3 July 2017.

6. Heininger U, Riffelmann M, Bär G, Rudin C, von König C-HW. The protective role of maternally derived antibodies against Bordetella pertussis in young infants. Pediatr Infect Dis J. 2013;32(6):6958 .

7. Rath BA, Register KB, Wall J, Sokol DM, Van Dyke RB. Persistent Bordetella bronchiseptica pneumonia in an immunocompetent infant and genetic comparison of clinical isolates with kennel cough vaccine strains. Clin Infect Dis. 2008;46(6):905-8.

8. WHO. Pertussis vaccines: WHO position paper. August 2015. Disponible en: http://apps.who.int/iris/
bitstream/10665/242413/1/WER9035_433-458.PDF

Accessed on 3 July 2017.

9. Lugnér AK, Van Der Maas N, Van Boven M, Mooi FR, de Melker HE. Cost-effectiveness of targeted vaccination to protect new-borns against pertussis: comparing neonatal, maternal, and cocooning vaccination strategies. Vaccine. 2013;31(46):5392-7.

10. Kharbanda EO, Vazquez-Benitez G, Lipkind HS, Klein NP, Cheetham TC, Naleway AL, et al. Maternal Tdap vaccination: coverage and acute safety outcomes in the vaccine safety datalink, 20072013. Vaccine. 2016;34(7):968-73.

11. Westra T, Vries R, Tamminga J, Sauboin C, Postma M. Cost-Effectiveness analysis of various pertussis vaccination strategies primarily aimed at protecting infants in the Netherlands. Clin Therapeutics. 2010;32(8):1479-95.

12. Van Hoek AJ, Campbell H, Amirthalingam G, Andrews N, Miller E. Cost-effectiveness and programmatic benefits of maternal vaccination against pertussis in England. $\mathbf{J}$ Infection. 2016;73(1):28-37.

13. Terranella A, Asay GR, Messonnier ML, Clark TA, Liang JL. Pregnancy dose Tdap and postpartum cocooning to prevent infant pertussis: a decision analysis. Pediatrics. 2013;131(6):1748-56.

14. Vilajeliu A. Goncé A, López M, Costa J, Rocamora L, Ríos J, et al. Combined tetanus-diphtheria and pertussis vaccine during pregnancy: transfer of maternal pertussis antibodies to the newborn. Vaccine. 2015;33(8):1056-62.

15. National Institute of Health, Ministry of Health of Colombia. Protocol of Surveillance in Public Health. Whooping cough. PRO-R02.013. Versión-03. 11junio-2014. Available at: http://www.ipsunipamplona.

com/es/images/sampledata/sivigila_2015/protocolos _epidemiologicos/PRO\%20Tos\%20ferina.pdf Accessed on 3 June 2017.

16. Department of Epidemiology. Ministry of Health. Chile's goverment. Whooping cough or whooping cough (CIE-10:A37.0-A37.9). Epidemiological situation, January-September 2015. Quarterly Epidemiological Bulletin. 2015;111(4).

17. Cohen R, Gaudelus J, Denis F, Stahl P, Chevaillier $\mathrm{O}$, Pujol $\mathrm{P}$, et al. Pertussis vaccination coverage among French parents of infants after 10 years of cocoon strategy. Med Infect Dis. 2016;46(4):188-93.

18. Pan American Health Organization. File disease: Tosferina (pertussis). Epidemiological alert. 16 de noviembre 2012. Available at http://www2.paho.org/hq/index.php?option=com_do cman\&task=doc_view\&Itemid $=270 \&$ gid $=19325 \&$ la ng=es Accessed on 3 June 2017.

19. Kharbanda EO, Vazquez-Benitez G, Lipkind HS, Klein NP, Cheetham TC, Naleway A, et al. Evaluation of the association of maternal pertussis vaccination with obstetric events and birth outcomes. JAMA. 2014;312(18):1897-904. 
20. Organización Mundial de la Salud. Estadísticas Sanitarias Mundiales. 2014. Disponible en: http://apps.who.int/iris/bitstream/10665/131953/1/97 89240692695_spa.pdf Accessed on 3 June 2017.

21. Baxter R, Bartlett J, Fireman B, Lewis E, Klein N. Effectiveness of vaccination during pregnancy to prevent infant pertussis. Pediatrics. 2017;139(5):e20164091:1-8.

22. Meregaglia M, Ferrara L, Melegar A, Demichel V. Parent "cocoon" immunization to prevent pertussisrelated hospitalization in infants: The case of Piemonte in Italy. Vaccine. 2013;31(8):1135-7.

23. Ministerio de Salud y Protección Social de Colombia. Lineamiento estratégico para la introducción de la vacuna TdaP (Tétanos - Difteria Tosferina acelular) en el esquema del programa ampliado de inmunizaciones [PAI] para mujeres gestantes de las cohortes 2013 y 2014. Disponible en: https://www.minsalud.gov.co/Documentos\% 20y\%20Publicaciones/lineamiento $\% 20$ Estrat $\%$ C3\% A9gico\%20para\%20la\%20Introducci\%C3\%B3n\%20 de\%201a\%20Vacuna\%20TdaP.pdf Accessed on 3 June 2017.

24. Maertens K, Caboré RN, Huygen K, Hens N, Van Damme P, Leuridan E. Pertussis vaccination during pregnancy in Belgium: results of a prospective controlled cohort study. Vaccine. 2016;34(1):142-50.

25. Omer SB. Maternal immunization. N Engl J Med. 2017;376:1256-67.

26. Abu Raya B, Bamberger E, Almog M, Peri R, Srugo I, Kessel A. Immunization of pregnant women against pertussis: The effect of timing on antibody avidity. Vaccine. 2015;33(16):1948-52.

27. Munoz FM, Bond NH, Maccato $M$, Pinell $P$, Hammill Ha, Swamy GK, et al. Safety and immunogenicity of tetanus diphtheria and acellular pertussis (Tdap) immunization during pregnancy in mothers and infants: a randomized clinical trial. JAMA. 2014;311(17)):1760-9.

28. Donaldson B, Jain P, Holder BS, Lindsay B, Regan L, Kampmann B. What determines uptake of pertussis vaccine in pregnancy? A cross sectional survey in an ethnically diverse population of pregnant women in London. Vaccine. 2015;33(43):5822-8.

29. Healy MC, Rench MA, Baker CJ. Importance of Timing of Maternal Combined Tetanus, Diphtheria, and Acellular Pertussis (Tdap) Immunization and Protection of Young Infants. Clin Infect Dis. 2013;56(4):539-44.

30. Hoang HT, Leuridan E, Maertens K, Nguyenb TD, Hens $\mathrm{N}, \mathrm{Vu} \mathrm{NH}$, et al. Pertussis vaccination during pregnancy in Vietnam: Results of a randomized controlled trial Pertussis vaccination during pregnancy. Vaccine. 2016;34(1):151-9.

31. Healy CM, Rench MA, Wootton SH, Castagnini LA. Evaluation of the impact of a pertussis cocooning program on infant pertussis infection. Pediatr Infect Dis. 2015;34(1):22-6.
32. Matlow J, Pupeo A, Bozzo P, Koren G. Tdap vaccination during pregnancy to reduce pertussis infection in young infants. Can Fam Physician. 2013;59:497-8.

33. Abu Raya B, Srugo I, Kessel A, Peterman M, Bader $\mathrm{D}$, Gonen R, et al. The effect of timing of maternal tetanus, diphtheria, and acellular pertussis (Tdap) immunization during pregnancy on newborn pertussis antibody levels - a prospective study. Vaccine. 2014;32(44):5787-93.

34. Amirthalingam G, Andrews N, Campbell H, Ribeiro $\mathrm{S}$, Kara E, Donegan $\mathrm{K}$, et al. Effectiveness of pertussis maternal vaccination in England: an observational study. Lancet. 2014;384(9953):1521-8.

35. Carcione D, Regan AK, Tracey L, Mak DB, Gibbs $\mathrm{R}$, Dowse GK, et al. The impact of parental postpartum pertussis vaccination on infection in infants: a population-based study of cocooning in Western Australia. Vaccine. 2015;33(42):5654-61.

36. Dabrera G, Amirthalingam G, Andrews N, Campbell H, Ribeiro S, Kara E, et al. A case-control study to estimate the effectiveness of maternal pertussis vaccination in protecting newborn infants in England and Wales, 2012-2013. Clin Infec Dis. 2015;60(3):333-7.

37. Vizzotti C, Juarez MV, Bergel E, Romanin V, Califano G, Sagradini S, et al. Impact of a maternal immunization program against pertussis in a developing country. Vaccine. 2016;34(50):6223-8.

38. Castagnini LA, Healy M, Rench MA, Wootton SH, Muñoz FM, Baker CJ. Impact of maternal postpartum tetanus diphtheria toxoids and acellular pertussis immunization on infant pertussis infection. Clin Infect Dis. 2012;54(1):78-84.

39. Libster R, Edwards KM. How Can We Best Prevent Pertussis in Infants? Clin Infec Dis. 2012;54(1):85-7.

40. Gall SA, Myers J, Pichichero M. Maternal immunization with tetanus-diphtheria-pertussis vaccine: effect on maternal and neonatal serum antibody levels. Am J Obstet Gynecol. 2011;204(4):334:1-5.

41. Skowronski DM, Janjua NZ, Tsafack EP, Ouakki M, Hoang L, De Serres G. The number needed to vaccinate to prevent infant pertussis hospitalization and death through parent cocoon immunization. Clin Infect Dis. 2012;54(3):318-27.

42. Fernández-Cano M, Armadans-Gil L, CampinsMartín M. Cost-benefit of the introduction of new strategies for vaccination against pertussis in Spain: cocooning and pregnant vaccination strategies. Vaccine. 2015;33(19):2213-20.

43. Centers for Disease Control and Prevention (CDC). Updated recommendations for use of tetanus toxoid, reduced diphtheria toxoid, and acellular pertussis vaccine (Tdap) in pregnant women. Advisory Committee on Immunization Practices (ACIP), 2012. MMWR. 2013;62(7):131-5.

44. Berenson AB, Hirth JM, Rahman M, Laz TH, Rupp RE, Sarpong KO. Maternal and infant outcomes among women vaccinated against pertussis during 
pregnancy. Hum Vaccin Immunother. 2016;12(8):1965-71.

45. Sukumaran L, McCarthy NL, Kharbanda EO, Weintraub ES, Vazquez-Benitez G, McNeil MM, et al. Safety of tetanus toxoid, reduced diphtheria toxoid, and acellular pertussis and influenza vaccinations in pregnancy. Obstet Gynecol. 2015;126(5):1069-74.

46. Morgan JL, Baggari SR, McIntire DD, Sheffield JS. Pregnancy outcomes after antepartum tetanus, diphtheria, and acellular pertussis vaccination. Obstet Gynecol. 2015;125(6):1433-8.

47. Zheteyeva YA, Moro PL, Tepper NK, Rasmussen SA, Barash FE, Revsina NV, et al. Adverse event reports after tetanus toxoid, reduced diphtheria toxoid, and acellular pertussis vaccines in pregnant women. Am J Obstet Gynecol. 2012;207(1):1-7.

48. Sartori AM, de Soárez PC, Fernandes EG, Gryninger LC, Viscondi JY, Novaes HM. Cost-effectiveness analysis of universal maternal immunization with tetanus-diphtheria-acellular pertussis (Tdap) vaccine in Brazil. Vaccine. 2016;34(13):1531-9.

49. Centers for Disease Control and Prevention (CDC). Updated recommendations for use of tetanus toxoid, reduced diphtheria toxoid and acellular pertussis vaccine (Tdap) in pregnant women and persons who have or anticipate having close contact with an infant aged $<12$ months. Advisory Committee on
Immunization Practices (ACIP), 2011. MMWR. 2011;60(41):1424-6.

50. Winter K, Nickell S, Powell M, Harriman K. Effectiveness of prenatal versus postpartum tetanus, diphtheria, and acellular pertussis vaccination in preventing infant pertussis. Clin Infect Dis. 2017;64(1):3-8.

51. Forsyth K, Plotkin S, Tan T, Wirsing von König CH. Strategies to decrease pertussis transmission to infants. Pediatrics. 2015;135:1475-82.

52. Healy CM, Rench MA, Montesinos DP, $\mathrm{Ng} \mathrm{N}$, Swaim LS. Knowledge and attitiudes of pregnant women and their providers towards recommendations for immunization during pregnancy. Vaccine. 2015;33(41):5445-51.

53. Strategic Advisory Group of Experts (SAGE) on immunization. Meeting of the Strategic Advisory Group of Experts on immunization, October 2009 Conclusions and recommendations. Biologicals. 2010;38:170-7.

Cite this article as: Monterrosa-Castro A, RamirezGarcía A, Beltrán-Barrios T. Benefits of maternal vaccination to prevent pertussis in infants. Int J Reprod Contracept Obstet Gynecol 2017;6:4179-86. 